\title{
CAN FAMILY BUSINESS MANAGERS MANAGE FAMILY BUSINESS RISKS?"
}

\author{
Thea Visser ${ }^{* *}$ \\ Louise van Scheers ${ }^{* * *}$
}

Received: 19. 7. 2016

Preliminary communication

Accepted: 23. 4. 2018

UDC 005.334:330.342.11

DOI https://doi.org/10.30924/mjcmi/2018.23.1.123

\begin{abstract}
The purpose of this conceptual paper was to investigate risk management in the family business. Risk management poses challenges to family business's survival, as family members do not take actions on risk. Family members find managing risk difficult; therefore, they prefer to avoid taking actions. The assessment of risk is difficult and family businesses lack the ability to determine risk management priorities, including risk management review processes to evaluate risk. Risk priorities should be refocused to be in line with the strategic direction of the family business. Family business owners should also seek agreement on the risk goals of the business. Managing
\end{abstract}

\section{INTRODUCTION}

Families limit their definitions of family business risk management to the traditional dimensions of investment, performance and insurance risk (Bernard, 2014). Daniell and Hamilton (2010) argue that family advisors need to respond appropriately to family members' definition of risk. Unclear roles of family members in the business and a lack of communication are the main risks for the risk effectively will assist the family business to perform well and to maintain sustainable growth. Since very little research is conducted on risk management in the family business, this paper contributes to the existing literature by unpacking risk management in the family business context. The research concluded that managers should be educated on how to define acceptable risk in the financial area. The research recommends that family business managers should have a historical perspective on finance, as it will assist in identifying risk management areas.

Keywords: family business, risk management, risk types, risk-taking, risk aversion, risk management strategies, financial risk

succession of the family business (Lipitz and Hauser, 2016). Research by the Family Enterprise Risk Index showed that less than one-third of risk management plans for family businesses cover risks to the family itself (Lipitz and Hauser, 2016). Dipietro (2015) mentions that the biggest risks facing the family business include issues with succession and those that harm the family's reputation. Daniell and McCullough (2013) are

\footnotetext{
* The first author acknowledges the College of Economic and Management Sciences, University of South Africa, for the granting of research and development leave.

** Thea Visser, University of South Africa, Department of Business Management, P.O. Box 392, University of South Africa, Pretoria, 0003, South Africa, Phone:+27 83207 3997, e-mail: vissed@unisa.ac.za

${ }^{* * *}$ Louise van Scheers, University of South Africa, College of Economic and Management Sciences, Department of Marketing and Retail Management, e-mail: vschem1@unisa.ac.za
} 
concerned that unmanaged and misunderstood risks can be harmful for the succession of the family business. Crystal (2015) emphasizes that failing to take actions on risk is an area where many family businesses fail, resulting in great family fortune losses that are all due to the lack of risk management.

According to Daniell and McCullough (2013), family members find risk management difficult; and as Senegović et al. (2015) observe, they prefer to avoid it. Le BretonMiller et al. (2013) emphasize that risks in the family business are managed differently because they experience fewer external restrictions regarding controls on business activities. However, Ratten (2015) explains that although family businesses are prepared to risk financial losses and run a great risk of failure to maintain control of the firm (Gómez-Mejía et al., 2013), they still avoid managing family risks. Management and ownership are not clearly separated (Senegović et al., 2015), creating yet another family risk; while a high level of ownership concentration fosters risktaking (Nguyen, 2011).

The importance of family businesses is well recognized globally, and the International Family Enterprise Research Academy notes that between $80 \%$ and $95 \%$ of all private companies worldwide are family businesses (Senegović et al., 2015). Family businesses contribute to wealth creation, create new jobs (Westhead et al., 2011; Gómez-Mejía et al., 2013; Ramadani and Hoy, 2015), and employ more than $85 \%$ of the total number of employees (Senegović et al., 2015). According to Ramadani and Hoy (2015), family businesses have an impact on economic development and growth. Research conducted by the Family Firm Institute (2013) showed that $30 \%$ of family businesses survive into the second generation. Ten percent are still viable into the third generation, while only $3 \%$ operate into the fourth generation (Family Firm Institute, 2013). The average life span of the family business is 24 years (Argüden, 2011; Senegović et al., 2015), which demonstrates different generational attitudes towards risk issues, and consequently, growth and sustainability issues (Senegović et al., 2015).

Many risk management areas are still under-studied (Verbano and Venturini, 2013), particularly in the family business context (Lumpkin and Dess, 2013; Hiebl, 2013). Both the content and process of risk management are the subjects of "recent scrutiny" and building approaches that monitor a broader set of risks and responding more quickly to warning signals, are priorities for most families (Daniell and Hamilton, 2010). The authors of this paper want to address the existing gap in the literature. The purpose and objective of the paper are therefore to investigate risk management in the family business. The paper is organised as follows: firstly, the research methodology is presented; secondly, the literature overview defines family business risk and risk selection, categorization and characteristics. Risk types, risk-taking and risk aversion, risk management strategies and financial risk are analysed. Thirdly, a discussion of the results follows; and finally, the conclusion is presented. The concluding section points to the need for family business managers to have a historical perspective on finance, as it assists in identifying risk areas. Managing risk effectively assist the family business to perform well and to maintain sustainable growth.

\section{RESEARCH METHODOLOGY}

This study undertook secondary research to investigate risk management in the family business. The study was a preliminary, conceptual study for subsequent research in this field. The study was essentially textual 
as a substantial corpus of literature was consulted mainly from family business research articles, more general outlet articles, reports, and family business-related books and chapters. These publications can be categorized as relating to family businesses, family-controlled firms, strategy, risk management, entrepreneurship, governance, financial management, leadership, performance, risk-taking, risk planning, and family wealth. Risk management in an academic setting is a multidisciplinary subject, as shown by the heterogeneity of the literature used. The overview reveals several perspectives emerging from the field of the family business that may inform and assist in developing an understanding of risk management; and thus, may be of interest to family business scholars. The paper proceeds as follows: a literature overview is provided, then the subsequent section focuses on a discussion of results, followed by the conclusion.

\section{LITERATURE OVERVIEW}

In this section, the authors provide more insight into risk management in the family business context under the following subheadings: family business risk; risk selection criteria, categorization and characteristics; risk types; risk-taking and risk aversion; risk management strategies; and financial risk.

\subsection{Family business risk defined}

Family business risk is the probability of loss inherent in business operations, including the environment that impair the business's ability to provide returns on investment (Web Finance Incorporated, 2013). Family business risk can also be the possibility that the business will have lower than anticipated profits (Investopedia, 2013), while the business may experience a loss due to uncertainty of business objectives (Standards Australia/Standards New Zealand Standard
Committee, 2009). According to Daniell and McCullough (2013), the definition of family business risk is a case-specific exercise: for many families of different levels of wealth, the best definition of family business risk may be "not being able to meet business goals", or "not having the money to do what the business wants to do when members want to do it". A key outcome is that the definition of family business risk may need to be revisited by the family business to supplement volatility with a more nuanced and tailored view (Daniell and McCullough, 2013). Family business risk selection criteria, categorization and characteristics are presented in the next section.

\subsection{Risk selection criteria, categorization and characteristics}

Joshi and Srivastava (2013) claim that inconsistent results among studies emanate from problems with the definition of the family business. Some family firms are not necessarily owner-led, nor are all agent-led firms perceived as non-family firms (Joshi and Srivastava, 2013). This lack of a common definition of the family business impacts on a risk selection criteria and categorization, and specifically regarding the number of family members and employees; and, on the revenue of the family business. However, Altman et al. (2010) highlight that family business risks are classified according to (a) financial information; and (b) non-financial information. Financial information refers to family business accounts; and information that relates to assets, retained profit measures, leverage, and working capital. Nonfinancial information refers to the size, age and ownership of the business. Non-financial data include the family board size (number of directors), firm size, firm age, parentage (subsidiary or independently owned), the sector, and diversification (Wilson et al., 2013). 


\section{Journal of Contemporary Management Issues}

Family businesses have unique characteristics that affect their risks. These risks relate to the succession, governance, ownership, decision-making and performance of the business (Gudmonson et al., 1999; Reid and Adams, 2001; Ward, 2004). Shanker and Astrachan (1996) argue that family businesses are classified on percentage of ownership, power over strategic decisions, voting control, active management of family members and the involvement of multiple generations. Three categories of family businesses are identified by Akbar and Joshi (2012), which include: firstly, first generation founder-managed firms (founder firms); secondly, businesses started by institutions (state-owned enterprises or business group firms) but managed by professional managers (professional firms); and thirdly, a category that represents businesses owned and controlled by family members (family firms). The literature revealed typical characteristics of family businesses, as presented in Table 1.
Akbar and Joshi (2012) opine that the selection, categorization and characteristics of family businesses are unclear. Risk types of family businesses are outlined in the next section.

\subsection{Family business risk types}

The most pervasive family business risk types (quadrants) are presented in Table 2. Risk assessment should, therefore, be proactive and structured to identify the unique risks associated with each business (Downing, 2012).

The first risk quadrant (Business Ownership and Control) highlights issues that exist while the family is still involved in the founding family members' business. These issues include business strategy, governance, operations and finance, and issues embodied within the larger family (interpersonal dynamics, leadership succession, decision-making). The second quadrant (Wealth Preservation and Enhancement) deals with

Table 1. Family Business Characteristics

\begin{tabular}{|l|l|}
\hline \multicolumn{2}{|c|}{ Ownership } \\
\hline Family & Outside Investors \\
Centralized control, flat structures & Multiple-firm businesses \\
Lack of structure and systems & Equity crossholding \\
Informal relations and communications & Funding from bank/capital markets \\
Altruistic leadership style & Well-developed structures/systems \\
Poor knowledge management & Formal relations and communication \\
Relatively unqualified personnel & Better knowledge management \\
Uncertain succession & Highly skilled personnel \\
& Family succession well defined \\
\hline Professionalized Firms & Investor Driven Firms \\
& \\
Multi-firm businesses & Multi-divisional structure \\
Reduced crossholding & Direct investor holdings \\
Funding by capital markets & Funding from capital markets \\
Well-defined structures/systems & Well defined structures/systems \\
Excellent knowledge management & Excellent knowledge management \\
Highly talented professionals & Most attractive to best talent \\
Erratic succession of professionals & Planned succession \\
\hline
\end{tabular}

Source: Akbar and Joshi, 2012. 
Table 2. Risk Types of the Family Business

\begin{tabular}{|l|l|}
\hline $\begin{array}{l}\text { Business Ownership and Control } \\
\text { (Quadrant 1) }\end{array}$ & $\begin{array}{l}\text { Wealth Preservation and Enhancement } \\
\text { (Quadrant 2) }\end{array}$ \\
Family control & $\begin{array}{l}\text { Investment goals and objectives } \\
\text { Family leadership of business }\end{array}$ \\
Family dynamics & Manager selection \\
Alignment of interest & Investment performance \\
Business strategy & Public equity concentration \\
Business governance & Private equity control \\
Business operations & Private equity distressed situations \\
\hline Financial Reporting and Compliance & Family Unity and Governance \\
(Quadrant 3) & (Quadrant 4) \\
Legal exposure & \\
Fiduciary roles and responsibilities & Family legacy \\
Wealth transfer protection & Philanthropic legacy \\
Physical asset protection & Family governance and decision-making \\
Financial leverage & Family relationships \\
Financial oversight & Family reputation and public image \\
Financial reporting/compliance & Personal security and privacy \\
Family office oversight & Personal health and wellness \\
\hline
\end{tabular}

Source: Family Office Exchange (FOX), 2007; Daniell and Hamilton, 2010.

traditional notions of risk management. It includes issues relating to asset diversification, investment objectives and performance, and manager selection. Technical and tactical areas of estate planning, financial reporting and regulatory compliance are highlighted in the third quadrant (Financial Reporting and Compliance). The fourth quadrant (Family Unity and Governance) outlines the most challenging risks for the family to confront as these issues relate to sensitive matters of family relationships and reputation (Downing, 2012). The four quadrants clearly reflect both the range of risks and the diversity within any one category. Setting priorities on risk factors and types is therefore an important element in successful long-term risk management to protect, preserve, and enhance the family business.

The literature also revealed the following family business risk types, with an overlap between some risk areas. These risks types include (Gómez-Mejía et al., 2007; Daniell and McCullough, 2013; Deloitte, 2016; EYGM Limited, 2016):

- Interbranch/intergenerational conflict risk: where formal family governance must still be established, or where formal mechanisms of family organization and leadership are ignored.

- Compliance risk: overlooking (new) tax laws, or other aspects in the regulatory environment. This risk becomes larger as the pace of legislative change quickens.

- Process risk: It can be easier for family decision-makers to override disciplines, to ignore essential steps in the process; and assert the value of "gut feelings" in investment processes.

- Resource risk: families can be at risk of deploying too limited a set of resources, accessing too little information, or 
spreading limited resources too thinly, which can result in poor decision-making.

- Competence risk: a great risk that families face in ensuring that family members who are active on the investment side are as competent as their institutional colleagues.

- Succession risk: the role of the family leader carries with it far greater weight than an institutional chief executive officer (CEO).

- Relationship breakdown risk: friction/ frustration boiling over into family conflict can carry with it the risk of distraction, dysfunctional competition, intrusive disorder and lingering resentment.

- Culture, vision and values' risk: values, behaviours and operating styles that make up the family culture can be either a great support, or a handicap in investing.

- Venturing/entrepreneurial risk: it signifies the search for new opportunities to increase business performance, taking into consideration unexpected outcomes and performance variance.

- Technology risk: loss of information and infringement of confidentiality, and information and identity theft.

- Ecosystem risk: having the wrong advisors or accepting the wrong advice, can be more of a risk for the family than an institution. Selecting, assessing and managing advisors require expertise and an objective view of performance.

Family members express themselves in different ways, and therefore, the interrelatedness between the different family business risk types. Risk-taking and risk aversion as family business challenges follow in the next section.

\subsection{Risk-taking and risk aversion}

Various authors (Chrisman et al., 2011; Zahra, 2013; Senegović et al., 2015), emphasize that the challenge for a family business lies in the complexity of entrepreneurial risk-taking as most family businesses lack entrepreneurial skills. Brigham (2013) observes that entrepreneurial risk-taking is not well understood, while Zahra (2013) objects that it is not systematically studied. Schwass et al. (2011) point out that risk-taking is an entrepreneurial trait, associated with family founders; however, becoming an entrepreneur means overcoming risks of all types. As emphasized by Schwass et al. (2011), the biggest risk is "not to take any risk" and the key risk for family entrepreneurs is how to structure the future of the business beyond their own life span. The risk can be that the next generation is inadequately prepared for an effective power-sharing structure. Gómez-Mejía et al. (2013) argue that family businesses are less innovative because they prefer to avoid the risk of failure that is associated with new and "untried" activities.

Therefore, fostering entrepreneurs' activities in future generations is a good way to keep wealth and the family together over longer times. Families need to counteract the tendency for the entrepreneurial spirit to dissipate gradually in younger generations, while stressing their risk-taking (Schwass et al., 2011). New businesses, specifically, cannot be launched without the ability to assess risk accurately and to live with uncertainty. Risk tolerance is therefore critical to managing the business in the long term. Risk-taking serves as a motivator for first-generation family businesses, while risk avoidance is a motivator for second generations. Families cannot preserve wealth beyond three generations without evaluating reasonable risktaking levels (Daniell and Hamilton, 2010). The authors also highlight that calculated risk-taking is an important part of the family 
business to be embedded in the culture of the family, and to sustain the family legacy. Pendergast et al. (2011) stress that as the business and its workforce grow, so too does the need for the management team to understand its risk-taking philosophy. Welsh and Zellweger (2010) state that female family managers take on less risk than male familymanagers. Many societies may not see women taking risks as some cultures do not expect them to take risks (Shapiro et al., 2015). The authors emphasize that women may be less visible and less recognized. Therefore, they need to make their risks more visible and capture the credit for risk-taking in ways that signal their success to those around them, such as to name the risk, articulate the cost-benefit calculation, and promote accomplishments by letting decision-makers know about their risk actions.

Various authors observe that the involvement of multiple generations increases risk aversion (Memili et al., 2011; Le BretonMiller et al., 2011; Anderson et al., 2012), while more than one generation in the business increases risk-taking behaviour (Casillas et al., 2010; Casillas et al., 2011). González et al. (2013) note that non-family equity owners (institutional investors, venture capital firms) exert pressure on the management team to take on more risk to enhance performance. According to GómezMejía et al. (2013), family businesses are risk-willing and risk-averse at the same time. Hiebl (2013) observes that family businesses have a high degree of risk aversion, as higher risk endangers the succession and survival of the family business. Moreover, owners tend to have large parts of their wealth invested in the business, which further increases their aversion to risky ventures (Bianco et al., 2013). Hiebl (2012) claims that these notions lead to the assumption that family businesses are more risk-averse than nonfamily businesses. The next section outlines risk management strategies for the family business.

\subsection{Risk management strategies}

Families need to manage a broad and unique set of risk management strategies (Daniell and Hamilton, 2010; Daniell and McCullough, 2013). Lipitz and Hauser (2016) point out that the inability to determine risk management priorities is a major obstacle for the family business. According to Daniell and McCullough (2013), "soft" family business risks include: unwarranted arrogance, inadequate self-knowledge (or assessment), a lack of education and preparation, as well as inadequate succession planning or wealth transition, a lack of formal governance or informal leadership, a dysfunctional culture and resulting conflict, personal family disputes, competition for leadership positions in the family, and in its business and investing activities, litigation and marital complexity, and in-laws. The authors also emphasize the following as "family" risks: family harmony, continuity and risk (disputes, marital issues, litigation); physical security risk (health, privacy, security, information theft); ecosystem risk (hiring the wrong staff members/advisors); longevity and mortality risk (outliving money, no will/estate plan); and key person risk (degree of capability, control and influence). In addition, Daniell and Hamilton (2010) argue that family businesses lack business experience to develop risk management strategies, resulting from a false sense of capabilities or an under-estimation of how hard it is to compete and be successful in the "real world".

According to Maynard et al. (2012), risk management strategies reduce or avoid unintended and unacceptable consequences of activities and decisions. In maintaining strategic vitality, Aronoff and Ward (2011) note that it requires business (leaders) to risk change and to embrace future-focused 
approaches to invigorate the business more than stale, immovable strategies. The authors are concerned that a strategy based on "the way we do things here" is by definition limiting and is not geared to meet the business's needs, nor is it likely to encourage motivation and commitment throughout the family ranks. Risks threatening business members' ability to interact and communicate effectively with one another, affect the future of all relatives (Daniell and Hamilton, 2010). Aronoff and Ward (2011) highlight that emotional risks are reduced by introducing change incrementally. The business should therefore move slowly in a few new directions to see which direction works under which circumstances, as this will make change more palatable, both emotionally and financially.

A key leadership skill in the family business is the ability to manage risks and to take the necessary precautions. It is therefore essential to prepare the family leadership for potential risks by identifying early signs in different risk areas (Argüden, 2011). Lipitz and Hauser (2016) argue that the risk management responsibilities and decisions depend on the structure of the business. Communication processes become regimented in case of a formal family business structure. A study by Carney (2013) found that weak risk-bearing, altruism and nepotism harm the longevity and efficiency of the family business. Even if owners within a generation share a unified vision of strategic goals, divergent risk tolerances may create conflict that sabotages successful implementation (Aronoff and Ward, 2011).

Safari et al. (2016) argue that risk analysis is a critical step in risk management and in strategic decision-making. It involves an evaluation of the impact and probability of risk events (Pritchard, 2015). Failure mode and effects analysis (FMEA) could be used to mitigate and manage risks (Santos et al., 2012). The goal of FMEA could ultimately be to align a family business risk with its source as closely as possible (Razak and Sorooshian, 2015). The overview concludes with a discussion of financial risk as the sustainability and growth of the family business are ensured by financial success.

\subsection{Financial risk}

Research has found that family-controlled businesses in public markets outperform non-family-controlled businesses (Daugherty, 2013). Various authors contend that the capital structure affects the risk of the family business and the risk to which managers are exposed (McConaughy et al., 2013). McConaughy et al. (2013) view capital structure as the proportion of debt to equity, rather than as specific types of securities used to finance capital investments. Managers must consider the risks for the business, including financial risks. For some owners, the ultimate risk may be the loss of capital or the loss of financial security (Daniell and Hamilton, 2010).

Various authors emphasize financial risks as the potential for gain or loss at a financial level - measured in terms of revenue, return on investment and equity, shareholder value, profitability, debt level, capital expenditure, and free cash flow (Daniell and Hamilton, 2010; Daniell and McCullough, 2013; Fassler and Sage-Hayward, 2015). Notably, Fassler and Sage-Hayward (2015) differentiate between: performance risk (potential for increased/decreased performance of the business - operations, production, materials, human resources), reputational risk (potential for gain/loss to the standing/status of the family and the business, including its name, brand, products/services - ethics, safety, security, quality, innovation, sustainability), non-family risk (potential for solidifying or weakening the rapport and trust 
with customers, employees, suppliers, other stakeholders - contractual, financial, procedural, communication, safety), family risk (potential for strengthening or abating trust and cohesion with the family), and safety risk (potential for creating harm or increasing the protection of people, goods, properties - compliance, regulatory, training, operational, procedural).

Managing financial risk effectively helps the family business to perform well and to maintain sustainable growth (Bublić et al., 2013). Morley (2015) emphasizes that certainty of revenue reduces risk, and a lack of certainty of revenue increases risk. The family's ability to address known risks and to prepare for unknown risks (the "unknown unknowns") strengthen the financial outcomes of the business, while addressing both known and unknown risks are important for the family (Family Office Exchange, 2009; Daniell and Hamilton, 2010). Risks that are easy to quantify (known risks) include family life cyles, business success/failure, spending patterns amongst owners, tax policies, market returns, inflation, and individual life expectancy. Risks that are difficult to quantify (areas of uncertainty) are family dynamics, entrepreneurial instincts in family members, interaction of asset classes over time (i.e. correlation), systemic risk in financial markets and global infrastructure, and major shifts in government policy (Family Office Exchange, 2009; Daniell and Hamilton, 2010). Managers should be educated on how family owners define acceptable risk in disciplined financial terms, and it is therefore important to establish, communicate, and agree on specific financial criteria to guide strategic and tactical moves (Aronoff and Ward, 2011). As emphasised by Daniell and Hamilton (2010), a critical role of the family leadership is to guide the family through the risks it encounters over time.

\section{DISCUSSION OF RESULTS}

The purpose of this conceptual research was to investigate risk management in the family business. The conducted research study emphasizes that many family businesses fail because family members do not take actions on business risk.

\subsection{Risk selection, types, risk taking and risk aversion}

The literature revealed that the classification and categorization of family business risk are unclear as there is no common definition of what a family business is. Family businesses also have unique characteristics and distinct peculiarities affecting business risk. There is also an overlap between some business risk types. Family business members do not understand the concept of risk-taking. Family business entrepreneurs, specifically, tend to be less innovative as they avoid risk failures. An interesting finding is that families find it difficult to preserve wealth beyond three generations without evaluating reasonable risk-taking levels. The conducted research confirmed that family risk assessment and management need interactive communication between the family business members to manage family business risks, as illustrated in Figure 1.

\section{Figure 1. Family Business Risk Analysis} Framework

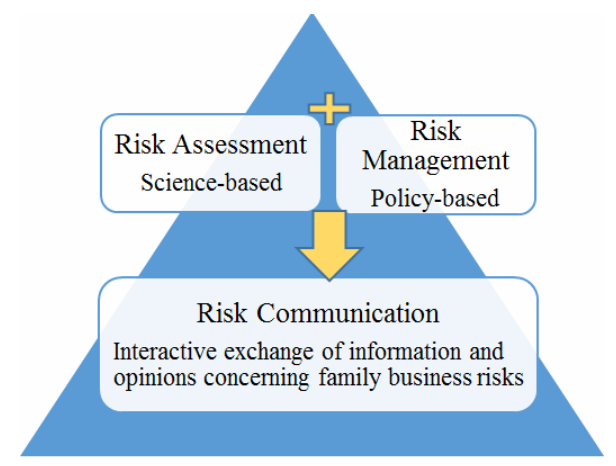

Source: Adapted from Crystal, 2015. 


\section{Journal of Contemporary Management Issues}

The conducted research also revealed that family businesses lack risk assessment (science-based) and risk management (policy-based) experiences, as indicated in Figure 1. Risk management priorities are challenging, as many family businesses do not have risk management policies and strategies in place to evaluate risks. Even if owners share a unified vision of strategic goals, divergent risk tolerances still create conflict that sabotages the implementation of strategic goals.

\subsection{Risk management strategies and financial risk}

The conducted research recommends that family business owners should seek agreement on risk goals that satisfy their interests and secure their commitment to the family business. These risk goals are:

- What risks are the business willing to take as an ownership group?

- What strategy presents the most or the least risk?

- What level of risk will be best for the business and the family?

The research confirmed that financial risks affect the family business as it helps the business to perform well and to maintain sustainable growth. Financial outcomes for the business are strengthened when known risks are addressed and preparations are made for unknown risks. The research also confirmed that the identification of financial risk areas guides strategic business goals. The conducted research derived from the Family Business Risk Management Process Model on how to manage different sets of risks within the family business (Figure 2).

The Family Business Risk Management Process Model (Figure 2) comprises four steps. The first step in this process is to define longterm family business goals, which is important for all areas of family risk management. Family business goals relating to risk management, and family members' roles and responsibilities, should be clearly stated.

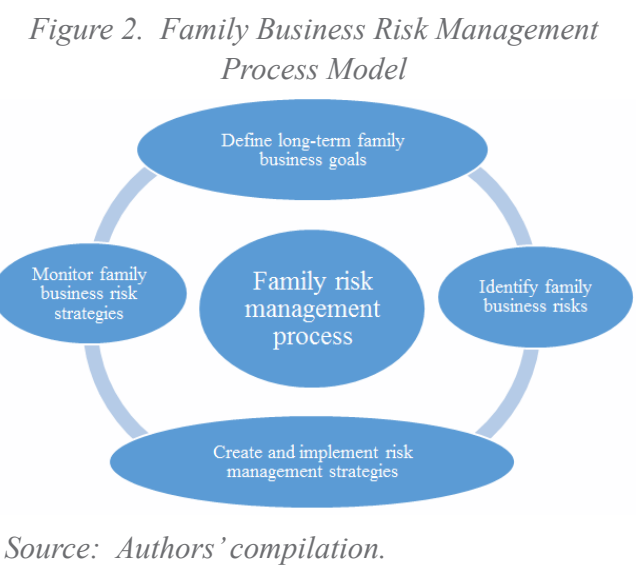

The second step is to identify possible family business risks. This step may be the most difficult stage in the process. Some risks are foreseeable, while other risks may be unique to a specific family. Various risks can also be identified; for example, family business continuity risk (family disputes) and longevity and mortality risk (outliving money, no will/estate plan). Some risks are also impossible to quantify by monetary measures and could be a threat to the continued viability of the family business. The third step in the process is to create and implement risk management strategies that should translate into an action plan. Priority risks should be analysed, and strategies should be formulated that the family can use to mitigate these risks. It is important to build processes and strategies that will enable families to make effective decisions during times of both stability and duress (Family Office Exchange, 2009). Furthermore, the implementation of risk management strategies is a long-term interactive process that must be continuously improved and integrated into the family businesses' overall strategic planning (Di Serio et al., 2011). The last step in the risk management process closes the risk continuum. The family business risk landscape should be continually monitored to identify any new risk. New family business risks surface because of the business's everchanging financial, legal, political and/or 
social environments (Downing, 2012). Risk assessment should be conducted, as it determines the probability and expected magnitude associated with the occurrence of the risk (Verbano and Venturini, 2013). It should also be ensured that family members have expert support to carry out risk assessment processes (Family Office Exchange, 2009).

As confirmed in the literature, risk analysis is a critical step of risk management; and therefore, FMEA could be used to analyse and prioritize risk areas. Family members should also understand different risk types, set family business goals and monitor strategies, as a complete risk management process protects the value of the family business.

\section{CONCLUSION}

The purpose of this conceptual research was to investigate risk management in the family business. The overview focused on family business risk, risk selection criteria,

\section{REFERENCES}

1. Akbar, M., Joshi, M. (2012). Endogenous agency problems, their impact and mitigation in privately-held family firms for sustaining growth. Amity Business Journal, 1(2), 1-22.

2. Altman, E.I., Sabato, G., Wilson, N. (2010). The value of non-financial information in small and medium-sized enterprise risk management. The Journal of Credit Risk, 6(2), 1-33.

3. Anderson, R.C., Duru, A., Reeb, D.M. (2012). Investment policy in family controlled firms. Journal of Banking \& Finance, 36(6), 1744-1758.

4. Argüden, Y. (2011). Keys to governance: Strategic leadership for quality of life. Hampshire, UK: Palgrave Macmillan.

5. Aronoff, C.E., Ward, J.L. (2011). Preparing your family business for categorization and characteristics, types of risks, risk-taking and risk aversion, risk management strategies and financial risk. The conducted research concluded that family business managers should be educated on how to define acceptable risk in disciplined financial terms. The research recommends that family business managers should have a historical perspective on finance, as it assists in identifying risk areas in the business. Family members in leadership positions should possess strong leadership skills to be able to anticipate future risks, prioritize risk areas, and put strategies in place to deal with family business risk types and areas. Risk management skills, specifically, enable family business owners and managers to address known risks, prepare for unknown risks, and to differentiate between financial risks that are easy to quantify and those more difficult to quantify. Managing risk effectively will enable a family business to perform well and to maintain sustainable growth.

strategic change. New York: Palgrave Macmillan.

6. Bernard, C. (2014). Family Risk Management Policies. http://www.kpmgfamily business.com/family-risk-management-policies [Accessed: 02/06/2016].

7. Bianco, M., Bontempi, M., Golinelli, R., Parigi, G. (2013). Family firms' investments, uncertainty and opacity. Small Business Economics, 40(4), 1035-1058.

8. Brigham, K.H. (2013). Social and economic impact of family business, in R.L. Sorenson, A. Yu, K.H. Brigham and G.T. Lumpkin, eds. The Landscape of Family Business. Cheltenham, UK: Edward Elgar, 78-92.

9. Bublić, V., Hunjak, T., VarlandySupek, M. (2013). Risk management in SMEs: The Croatian experiences, 
in V. Ramadani and R.C. Schneider, eds. Entrepreneurship in the Balkans: Diversity, Support and Prospects. Berlin: Springer, 57-76.

10. Carney, M. (2013). Corporate governance and competitive advantage in family-controlled firms, in J.H. Astrachan, K.S. McMillan and T.M. Pieper, eds. Family Business. Volume III. New York: Routledge, 135-155.

11. Casillas, J.C., Moreno, A.M., Barbero, J.L. (2010). A configurational approach of the relationship between entrepreneurial orientation and growth of family firms. Family Business Review, 23(1), 27-44.

12. Casillas, J.C., Moreno, A.M., Barbero, J.L. (2011). Entrepreneurial orientation of family firms: Family and environmental dimensions. Journal of Family Business Strategy, 2(2), 90-100.

13. Chrisman, J.J., Chua, J.H., Steier, L.P. (2011). Resilience of family firms: An introduction. Entrepreneurship Theory and Practice, 35(6), 1107-1119.

14. Crystal, J.H.F. (2015). Family-owned Businesses Struggle to Manage Risks. Risk and Compliance Journal. http://blogs.wsj.com/riskandcompliance/2015/01/21/family-owned-businesses-fall-sh [Accessed: 02/06/2016].

15. Daniell, M.H., Hamilton, S.S. (2010). Family legacy and leadership: Preserving true family wealth in challenging times. Singapore: John Wiley and Sons (Asia) Pte. Ltd.

16. Daniell, M.H., McCullough, T. (2013). Family wealth management. Singapore: John Wiley and Sons Singapore Pte. Ltd.

17. Daugherty, M.S. (2013). Performance in the family business: Financial and socioemotional outcomes, in R.L. Sorenson, A. Yu, K.H. Brigham and G.T. Lumpkin, eds. The Landscape of Family Business.
Cheltenham, UK: Edward Elgar Publishing Limited, 64-77.

18. Deloitte. (2016). Next-generation family businesses: Evolution keeping family values alive. Deloitte University EMEA CVBA.

19. Dipietro, B. (2015). Family-owned Businesses Struggle to Manage Risks. Risk and Compliance Journal. http://blogs.wsj.com/riskandcompliance/2015/01/21/family-owned-businesses-fall-sh [Accessed: 07/06/2016].

20. DiSerio, L.C., De Oliveira, L.H., Schuch, L.M.S. (2011). Organizational risk management - a case study in companies that have won the Brazilian Quatity Award Price. Journal of Technology Management and Innovation, 6(2), 230-243.

21. Downing, A. (2012). Risk management for financial families. Wells Fargo Bank, N.A.: Wells Fargo \& Company.

22. EYGM Limited. (2016). Preserving wealth through generations. United Kingdom: EYGM Limited.

23. Family Firm Institute. (2013). http:// www.ffi.org/?page=History [Accessed: 15/05/2013].

24. Family Office Exchange (FOX). (2007). Key risks faced by wealthy families, in H. Daniell and T. McCullough. Family Wealth Management. Singapore: John Wiley \& Sons Singapore Pte. Ltd, 149-184.

25. Family Office Exchange (FOX). (2009). Securing the future. Chicago, IL: Family Office Exchange.

26. Fassler, M.L., Sage-Hayward, W. (2015). Managing Risk in the Family Enterprise: It's More Than Financial. The Family Business Consulting Group, Inc. http://www.thefbcg.com/managingrisk-in-family-enterprise-more-thanfinancial [Accessed: 01/06//2016]. 
27. Gómez-Mejía, L.R., Haynes, K.T, Núñez-Nickel, M., Jacobson, K.J.L., Moyano-Fuentes, J. (2007). Socioemotional wealth and business risks in family-controlled firms: Evidence from Spanish olive oil mills. Administrative Science Quarterly, 52(1), 106-137.

28. Gómez-Mejía, L.R., Haynes, K.T., Núñez-Nickel, M., Jacobson, K.J.L., Moyano-Fuentes, J. (2013). Socioemotional wealth and business risks in family-controlled firms: Evidence from Spanish olive oil mills, in J.H. Astrachan, K.S. McMillan and T.M. Pieper, eds. Family Business. Volume 11. New York: Routledge, 168-206.

29. González, M., Guzmán, A., Pombo, C., Trujillo, M.A. (2013). Family firms and debt: Risk aversion versus risk of losing control. Journal of Business Research, 66(11), 2308-2320.

30. Gudmonson, D., Hartman, A., Tower, B. (1999). Strategic orientation: Differences between family and nonfamily firms. Family Business Review, 12(1), 27-39.

31. Hiebl, M.R.W. (2012). Peculiarities of financial management in family firms.

International Business and Economics Research Journal, 11(3), 315-322.

32. Hiebl, M.R.W. (2013). Risk aversion in family firms: What do we really know? Journal of Risk Finance, 14(1), 49-70.

33. Investopedia. (2013). http://www.investopedia.com/terms/b/businessrisk. asp [Accessed: 20/05/2013].

34. Joshi, M., Srivastava, A. (2013). Family business in transition: A case of PAL (Panchamrit Asbestos Ltd). Journal of Entrepreneurship in Emerging Economies, 6(1), 72-96.

35. Le Breton-Miller, I.L., Miller, D., Lester, R.H. (2011). Stewardship or agency: A social embeddedness reconciliation of conduct and performance in public family businesses. Organisation Science, 22(3), 704-721.

36. Le Breton-Miller, I., Miller, D., Lester, R.H. (2013). Stewardship or agency? A social embeddedness reconciliation of conduct and performance in public family businesses, in J.H. Astrachan, K.S. McMillan and T.M. Pieper, eds. Family Business. Volume 111. New York: Routledge, 391-425.

37. Lipitz, E., Hauser, B.R. (2016). Trusts and Estates: Managing Risk in Family Businesses. http://wealthmanagement.com/family-business/managingrisk-family-businesses [Accessed: 01/06/2016].

38. Lumpkin, G.T., Dess, G.G. (2013). Strategy in family business: Recent findings and future challenges, in R.L. Sorenson, A. Yu, K.H. Brigham and G.T. Lumpkin, eds. The Landscape of Family Business. Cheltenham, UK: Edward Elgar Publishing Limited, 93-112.

39. Maynard, A.D., Grobe, A., Renn, O. (2012). Responsible innovation, global governance and emerging technologies, in R.A. Parker and R.P. Appelbaum, eds. Can Emerging Technologies Make a Difference in Development? New York: Routledge, 168-187.

40. McConaughy, D.L., Mathews, C.H., Falko, A.S. (2013). Founding familycontrolled firms: Performance, risk, and value, in J.H. Astrachan, K.S. McMillan and T.M. Pieper, eds. Family Business. Volume 111. New York: Routledge, 443-462.

41. Memili, E., Chrisman, J.J., Chua, J.H (2011). Transaction costs and outsourcing decisions in small and medium-sized family firms. Family Business Review, 24(1), 47-61.

42. Morley, M. (2015). The public private partnership handbook: How to maximize 
value from joint working. London, UK: Kogan Page Limited.

43. Nguyen, P. (2011). Corporate governance and risk-taking: Evidence from Japanese firms. Pacific-Basin Finance Journal, 19(3), 278-297.

44. Pendergast, J.M., Ward, J.L., de Pontet, S.B. (2011). Building a successful family business board: A guide for leaders, directors, and families. New York: Palgrave Macmillan.

45. Pritchard, C.L. (2015). Risk management: Concepts and guidance. 5th ed. Boca Raton, FL: Taylor \& Francis Group.

46. Ramadani, V., Hoy, F. (2015). Context and uniqueness of family businesses, in L. Dana and V. Ramadani, eds. Family Businesses in Transition Economies. Switzerland: Springer, 9-37.

47. Ratten, V. (2015). Family business in sport organizations: Western experiences as lessons for transitional economies, in L. Dana and V. Ramadani, eds. Family Businesses in Transition Economies. Switzerland: Springer, 305-317.

48. Razak, N.A.A., Sorooshian, S. (2015). Case improvement based on lower quality mode and effects analysis. Journal of Advanced and Applied Sciences, 3(4), 145-151.

49. Reid, R.S., Adams, J.S. (2001). Human resource management - a survey of practices within family and non-family firms. Journal of European Industrial Training, 25(6), 310-320.

50. Safari, H., Faraji, Z., Majidian, S. (2016). Identifying and evaluating enterprise architecture risks using FMEA and fuzzy VIKOR. Journal of Intelligent Manufacturing, 27(2), 475-486.

51. Santos, R.N.C., Laura, M.M.S.C., Serra, J.P.B. (2012). FMEA of a tailings dam. Georisk: Assessment and Management of Risk for Engineered Systems and Geohazards, 6(2), 89-104.

52. Schwass, J., Hillerström, H., Kück, H., Lief, C. (2011). Wise health: Creating it - the entrepreneur, managing it - the family business, preserving it - the family office. Hampshire, England: Palgrave MacMillan.

53. Senegović, I., Bublić, V., Ćorić, G. (2015). Family business succession risks: The Croatian context, in L. Dana and V. Ramadani, eds. Family Businesses in Transition Economies. Switzerland: Springer, 175-197.

54. Shanker, M.C., Astrachan, J.H. (1996). Myths and realities: Family businesses' contribution to the U.S. economy - a framework for assessing family business statistics. Family Business Review, 9(2), 107-119.

55. Shapiro, M., Hass, S., Maxfield, S., Gupta, V. (2015). Risk aversion among women: Reality or simply "doing gender"? in M. Broadbridge and S.L. Fielden, eds. The Road Ahead. Handbook of Gendered Careers in Management: Getting in, Getting on, Getting out. Cheltenham, UK: Edward Elgar, 208-224.

56. Standards Australia/Standards New Zealand Standard Committee. (2009). AS/NZS ISO 31000:2009. Risk Management: Principles and Guidelines. Sydney: Standards Australia/Standards New Zealand Standard Committee.

57. Verbano, C., Venturini, K. (2013). Managing risks in SMEs: A literature review and research agenda. Journal of Technology Management and Innovation, 8(3), 186-197.

58. Ward, T. (2004). Cognition, creativity and entrepreneurship. Journal of Business Venturing, 19(2), 173-188.

59. Web Finance Incorporated. (2013). 
Business Dictionary: Web Finance Incorporated. http://www.businessdictionary.com/definition/business-risk. html [Accessed: 20/05/2013].

60. Welsh, D.H.B., Zellweger, T. (2010). Can we afford it? Investment decisions of family and non-family owners. Academy of Entrepreneurship Journal, 16(2), 21-41.

61. Westhead, P., Wright, M., McElwee, G. (2011). Entrepreneurship: Perspectives and cases. Essex, England: Pearson Education Limited.

62. Wilson, N., Wright, M., Scholes, L. (2013). Family business survival and the role of boards. Entrepreneurship Theory and Practice, 37(6), 1369-1389.

63. Zahra, S.A. (2013). Entrepreneurial risk taking in family firms, in J.H. Astrachan, K.S. McMillan and T.M. Pieper, eds. Family Business. Volume IV. New York: Routledge, 292-312.

\section{MOGU LI MENADŽERI U OBITELJSKIM PODUZEĆIMA UPRAVLJATI RIZIKOM OBITELJSKIH PODUZEĆA?}

\section{SAŽETAK}

Cilj ovog konceptualnog rada je analizirati upravljanje rizikom $u$ obiteljskim poduzećima. Upravljanje rizikom postavlja izazove pred preživljavanje obiteljskih poduzeća, ukoliko članovi obitelji ne poduzimaju odgovarajuće akcije. Oni mogu upravljanje rizikom percipirati kao teško, pa, samim tim, preferirati nepoduzimanje odgovarajućih akcija. Procjena rizika je teška, a obiteljskim poduzećima nedostaje sposobnosti za utvrđivanje prioriteta u upravljanju rizikom, uključivši procese procjene razina rizika. Pritom se $i$ prioriteti rizika trebaju drugačije postaviti, kako bi se uskladili sa strateškim smjerom obiteljskog poduzeća. Vlasnici obiteljskih poduzeća bi trebali težiti slaganju o ciljevima, vezanim uz poslovni rizik. Učinkovito upravljanje rizikom može pomoći obiteljskim poduzećima da dobro posluju i ostvare održivi rast. $S$ obzirom da se istraživanjem upravljanja rizikom u obiteljskim poduzećima do sada bavio mali broj studija, ovaj rad doprinosi postojećoj literaturi. Istraživanjem se zaključuje da bi menadžeri trebali biti educirani za definiranje prihvatljivog rizika u području financija. Preporučuje se da bi menadžeri obiteljskih poduzeća trebali imati i povijesnu perspektivu prema financijama, s obzirom da isto može pomoći u identificiranju područja upravljanja rizikom. 
